\title{
Morphological and morphometric analysis of skeletal muscle between male and female young adult Colossoma macropomum (Characiformes: Serrasalmidae)
}

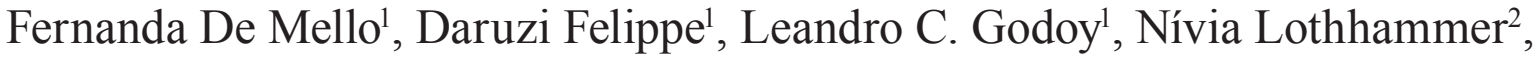 \\ Luis R. J. Guerreiro ${ }^{1}$ and Danilo P. Streit Jr. ${ }^{1}$
}

\begin{abstract}
This study aimed to evaluate muscle organization in tambaqui in order to describe the muscle growth process. We analyzed the morphometric pattern of fibers from white muscle of young-adults (300 days) by smaller diameter. The organization of white muscle exhibited a typical morphological pattern found in other fish species. Heavier animals showed higher frequency of larger diameter fibers $(>50 \mu \mathrm{m})$ and smaller animals had higher frequency of smaller diameter fibers $(<20 \mu \mathrm{m})(P=0.005)$. However, both animals showed the same frequency of intermediate diameter fibers $(20-50 \mu \mathrm{m})$. Body weight showed a positive correlation with muscle diameter fiber ( $\mathrm{r}=0.45)$, being $20-50 \mu \mathrm{m}$ the diameters that contributed the most to animal weight $(P<0.0001)$. A weak correlation between fiber diameter and animal sex was observed $(\mathrm{r}=0.2)$. Females showed higher frequency of large fiber diameters $(>50 \mu \mathrm{m})$ than males. However, there was no difference between body weight and sex $(P=0.8)$. Our results suggest that muscle growth is by hypertrophy and hyperplasia due to a mosaic appearance from different diameters fibers, which is characteristic of large size fish species.
\end{abstract}

O objetivo deste trabalho foi avaliar a organização muscular em tambaqui, a fim de descrever o processo de crescimento muscular. Foi analisado o padrão morfométrico das fibras do músculo branco de animais com 300 dias de idade usando o método de diâmetro menor. O músculo branco apresentou uma organização morfológica padrão encontrado em peixes. Animais de maior peso apresentaram maior frequência de fibras de maior diâmetro $(>50 \mu \mathrm{m})$ e os animais de menor peso apresentaram maior frequência de fibras de menor diâmetro $(<20 \mu \mathrm{m})(P=0,005)$. Entretanto, ambos os animais, com maior e menor peso, apresentaram frequências semelhantes de fibras de diâmetro intermediário (20-50 $\mu \mathrm{m})$. O parâmetro peso corporal mostrou correlação positiva com o diâmetro da fibra muscular $(\mathrm{r}=0,45)$, sendo as fibras de diâmetro intermediários $(20-50 \mu \mathrm{m})$ que mais contribuíram para o peso do animal $(P<0,0001)$. Fêmeas apresentaram maior frequência de fibras de maior diâmetro $(>50 \mu \mathrm{m})$ que machos. Observou-se uma fraca correlação entre o diâmetro da fibra e o sexo dos animais $(\mathrm{r}=$ $0,2)$. Apesar de fraca, a correlação estimada é corroborada pela fibras de grandes diâmetros $(>50 \mu \mathrm{m})$ serem mais frequente nas fêmeas que nos machos. No entanto, não houve diferença entre o peso corporal dos animais aos 300 dias de idade e sexo $(P=0,8)$. Os resultados encontrados sugerem que o crescimento muscular ocorre por hipertrofia e hiperplasia, caracterizado pela aparência em mosaico de fibras de diferentes diâmetros, característico de peixes de grande tamanho.

Keywords: Hypertrophy, Hyperplasia, Muscle growth, Sexing, Tambaqui.

\section{Introduction}

In fish, most species have indeterminate growth, implying that the size is never fixed and some growth continues throughout life (Rescan et al., 2013). Body growth is a multifactorial process involving intrinsic factors such as nutritional/metabolic or reproductive stages and also changes according to environmental factors such as temperature and photoperiod, which can affect muscle fiber recruitment (Volkoff et al., 2010). The knowledge on growth of muscle tissue is strategic in aquaculture industry because the muscle growth is directly correlated with the income from fish fillet. In this context, some fish species show sexual dimorphism, such as size dimorphism and shape dimorphism, making single-sex rearing more profitable (Mei \& Gui, 2015).

\footnotetext{
${ }^{1}$ Universidade Federal do Rio Grande do Sul, Departamento de Ciências Animais, 91540-000 Porto Alegre, RS, Brazil. (FM) fernandade. mello@gmail.com (corresponding author), (DF) daruz.cfpp@gmail.com, (LCG) godoyaqua@yahoo.com.br, (LRJG) luisbandeirantes@ hotmail.com, (DPSJr) danilo.streit@ufrgs.br.

${ }^{2}$ Universidade Federal do Rio Grande do Sul, Departamento de Ciências Morfológicas, ICBS, 90050-170 Porto Alegre, RS, Brazil. (NL) niayloth@gmail.com
} 
Post-larval development is dependent on two mechanisms of muscle fiber growth: hyperplasia and hypertrophy (Weatherley \& Gill, 1985; Weatherley, 1990; Veggetti et al., 1993). Thus, growth is associated with the recruitment of new fibers (hyperplasia) and/or the increase in the volume of muscle fibers (hypertrophy), such that the muscle may contain fibers with a wide range of diameters. In those fish species that ultimately reach a large size, continuous recruitment of muscle fibers in a long-lasting hyperplastic process gives a typical mosaic appearance to muscle cross-sections (Rowlerson \& Veggetti, 2001).

The Tambaqui, Colossoma macropomum (Cuvier, 1816) (Serrasalmidae, Teleostei) is the largest Characiformes of South America and an important aquaculture species widely distributed in the Amazon basin (Goulding \& Carvalho, 1982). Tambaqui is the Brazilian native species of highest production in continental fish farming, reaching 111,084.1 tons in 2011, surpassed only by tilapia production $(253,824.1$ tons) (MPA, 2013). The large production of this species is due to the flavorful fillet, which is largely composed by skeletal muscle white fibers, its good development in captivity and the control of reproductive cycle.

Long-term field surveys and fish farmers have observed size dimorphism between male and female individuals in tambaqui, but so far, such field surveys have not been proven. Indeed, on the premise that females mature later than males, the nutrients from diet would be directed to muscle growth and weight gain, leading females to reach a larger size. However, this is not valid for the tambaqui once the commercial slaughter takes place before the fish reach sexual maturity (Mello et al., 2015).

Previous studies have evaluated mostly the metabolism and physiology (Correa, 2007; Assis et al., 2007, 2010; Marcushi, 2010), reproduction (Carneiro et al., 2012; Maria et al., 2012; Galo et al., 2015), nutrition (SipaúbaTavares \& Braga, 2007) and genotoxicity aspects (da Rocha et al., 2011). However, knowledge about the skeletal muscle growth and morphology is limited to embryonic / larval and juvenile development, which does not describe the gain weight by muscle growth until slaughter phase (Alves-Costa et al., 2013).

In the present study, we describe the organization of skeletal muscle from two groups of the same strain showing different growth performances in order to determine muscle growth in 300-days-old tambaqui from captivity. We have also compared the muscle growth between males and females in order to correlate the growth with sex in this species.

\section{Material and Methods}

Farming system. Animals were farmed in grow-out ponds with $10 \%$ of water exchange a day, and a final biomass of $8000 \mathrm{~kg} / \mathrm{ha}$. Water temperature was $28 \pm 2{ }^{\circ} \mathrm{C}$, $\mathrm{pH}$ varied from 7.5 to 8.1 and dissolved oxygen (DO) from 3.5 to $11 \mathrm{mg} / \mathrm{L}$. Food (32\% of crude protein) was offered twice a day on a $3 \%$ of total biomass basis. The ponds were fertilized with $200 \mathrm{~g} / \mathrm{m}^{2}$ of organic material and additional fertilizations were carried out until the end of the first month, monitoring the water transparency.

Muscle samples. All procedures reported here were approved by the Animal Experimentation Ethics Committee of Federal University of Rio Grande do Sul (Process $N^{\circ}$ 23496). Ten 300-days-old tambaqui were sampled from the same husbandry in Pimenta Bueno City - RO (1140'29 67''S 61'11'27 67''W), grown between July 2010 and July 2011 (Table 1). For analyses, fish were divided into two groups according to their body weight; to the first group belonged to the smaller animals weighting from 165 to 300 grams $(235.8 \pm 66.61)$ and the second group to the larger ones weighting from 976 to 1250 grams $(10743.8 \pm 109.76)$. Muscle morphology evaluation and fiber diameter analysis were carried out by $1 \mathrm{~cm}^{2}$ samples of white muscle obtained from deep lateral line region, located close to the cranial region of the fish body. All samples were taken from the same anatomical position.

Histological techniques. Muscle samples were collected and immediately fixed in buffered formalin and posteriorly embedded in paraffin. Once fixed, a dehydration was performed by increase of alcohol degree (70, 80, 96 and 100), followed by immersion in xylene (twice) and two baths in paraffin, each sample remained 1 hour in each solution. Histological sections of $5 \mu \mathrm{m}$ in thickness, transverse and vertical, were obtained and subsequently stained with haematoxylin-eosin (HE) and Masson's trichrome (Bancroft \& Gamble, 2007) to evaluate the morphometric patterns of the muscle fibers. To stain, a deparaffinization was carried out using a xylene immersion for three times (20, 15 and 10 minutes, respectively) and the tissue was rehydrated by decreasing of the alcohol degree, 100 (3 $\mathrm{min}), 96$ (1 $\mathrm{min}), 80$ (1 $\mathrm{min})$ and 70 (1 min), followed by immersion in distilled water $(3 \mathrm{~min})$. For fish sex identification, gonads of each animal were collected from a ventral cut $(n=10)$ following the same histological procedure described above, and classified according to Vazzoler (1996).

Measurement of fiber size and assessment of hyperplasia and hypertrophy. The software Image $\mathrm{J}$ (Schneider et al., 2012) was used to determine the smallest diameter of each muscle fiber within a fiber population, and these diameters were used to evaluate the patterns of hypertrophic and hyperplastic growth of white muscle (Dubowitz, 1973). In accordance with a classification scheme that was proposed by Veggetti et al. (1993) the muscle fibers were categorized as belonging to three different size classes depending on their diameters: $<20 \mu m, 20-50 \mu m$ and $>50 \mu \mathrm{m}$ diameters. Mean and frequencies of fibers diameter were calculated in each class $(<20 \mu \mathrm{m}, 20-50 \mu \mathrm{m}$, and $>50 \mu \mathrm{m})$ with standard deviations. 
A high frequency of fibers having $<20 \mu m$ in diameter represents fibers recruited by hyperplasia and those exceeding this diameter, fibers having $>50 \mu \mathrm{m}$, represent subsequently grown by hypertrophy (Stickland, 1983; Weatherley and Gill, 1984; Weatherley et al., 1988). Thus, hyperplastic and hypertrophic growth in tambaqui was assessed using this established criterion in order to make comparisons to other fish species.

Data analysis. Differences of fiber diameters within and among groups were performed by ANOVA one-way and supplemented by Tukey's test $(P<0.05)$. Pearson's coefficient was used to measure the correlation between variables. All analyses were performed using the SAS 9.2 statistical package.

Table 1. Diameters of fibers in Colossoma macromum at 300 days old; body weight, sex, number of fibers sampled and means and standard error ( $\pm \mathrm{SE})$. (ND - Not Determined).

\begin{tabular}{ccccc}
\hline Samples & Body Weight $(\mathrm{g})$ & Sex & Number of Fibers & Mean \pm SE \\
\hline 1 & 308 & Female & 615 & $153.75 \pm 16.1$ \\
2 & 300 & Male & 545 & $136.25 \pm 7.5$ \\
3 & 178 & Male & 505 & $126.25 \pm 16$ \\
4 & 165 & ND & 444 & $111 \pm 0.9$ \\
5 & 228 & Female & 615 & $153.75 \pm 12$ \\
6 & 1,250 & Female & 455 & $113.75 \pm 8.0$ \\
7 & 990 & Female & 583 & $145.75 \pm 10$ \\
8 & 976 & Male & 119 & $119 \pm 7.3$ \\
9 & 1,093 & Male & 423 & $105.75 \pm 8.9$ \\
10 & 1,060 & Male & 531 & $132.75 \pm 13$ \\
\hline
\end{tabular}

\section{Results}

Muscle organization of white fibers. Striated muscle from tambaqui exhibited the typical morphologic pattern as other fish species, multinucleated fibers with peripheral nuclei (Figs. 1A, B). White fibers of tambaqui showed different diameters; are ensheathed by a layer of connective tissue, endomysium, in which are found capillaries and nerves. The perimysium is a sheath of connective tissue that brings together and keeps the fibers in fascicles in order to potentiate muscle action (Figs. 1C, D). Muscle fibers are inserted in connective tissue, where is possible to observe many nucleated cells, suggesting the process of cell differentiation and migration of these cells for newly generated myoblasts, which will be aligned and fused to generate new muscle fibers (Fig. 1E). Sarcomeres were visible throughout all the muscle fibers, almost completely filling the cytoplasm of the muscle cell (Fig. 1F).

It was possible to identify the process of muscle hypertrophy through the fusion of muscle cells surrounded by a cytoskeleton, forming the multinucleated myotubes that will further differentiate into mature muscle fibers (Fig. 2). However, the process of muscle growth is started by differentiation of satellite cells, which are precursors of muscle cells. Although the animals used in this study are considered young (300 days old), it was observed cell apoptosis occurring at some cells, but at low frequency (Fig. 3A).

Morphometric analysis. It was observed many small fibers between larger diameter fibers in all animals, giving a typical mosaic appearance with fibers of different sizes (Fig. 4). Frequency of fibers between $20-50 \mu \mathrm{m}$ of diameter was higher in smaller animals than the frequency of other fibers diameters $(P=0.05)$. In larger animals a higher frequency of larger fibers was observed, however, there was no difference between the fibers frequencies of $20-50 \mu m$ and $>50 \mu m(P=0.174)$. Correlation coefficient between the fibers diameters and body weight was 0.45 , being the 20-50 $\mu \mathrm{m}$ fibers that most contributed to the weight of the animals $(P<0.0001)$ (Fig. 5). Interestingly, the frequencies observed for larger fiber diameters $(>50$ $\mu m)$ are significantly different in animals with different body weights, although at the same age. The smallest animals had a higher frequency of smaller diameter fibers $(<20 \mu \mathrm{m})$ (more recently produced), despite also showing a mosaic of fibers with large diameters (20-50 $\mu \mathrm{m})$.

There is positive correlation between muscle fiber diameter and both body weight and sex with 0.2 and 0.45 , respectively. Body weight was accompanied by a continuous increase in fiber diameter (hypertrophy), confirmed in the plotted of parameters. There is correlation between fiber diameters and sex, despite low $(\mathrm{r}=0.2)$. Females showed higher frequency of larger fiber diameters $(>50 \mu \mathrm{m})$ than males, however, there were no differences between body weight and sex $(P=0.8)$.

\section{Discussion}

In this study, we analyzed only muscle fibers, also know as white fiber, which have fast twitch and constitute the major part of the myotomal musculature (Van Raamsdonk et al., 1982). Like others vertebrates, tambaqui satellites cells are located at the periphery of muscle fibers and connective tissue, where they migrate to fuse and form new fibers (Yin et al., 2013). Presence of many nuclei in the connective tissue suggests a differentiation and / or proliferation process for growth or maintenance of muscle tissue. Skeletal muscle relies upon regeneration to maintain homeostasis and repair injuries. This process involves the recruitment of the tissue's resident stem cell, the muscle progenitor cell, and a subsequent proliferative response by newly generated myoblasts (Stern et al., 2009). Considerable evidence indicates that small recruited fibers originate from the differentiation of myosatellite cells supporting mosaic hyperplastic growth and the presence of the satellite cells have been suggested to be a source of new fibers (Romanello et al., 1987; Veggetti et al., 1993; Rowlerson \& Veggetti, 2001). 


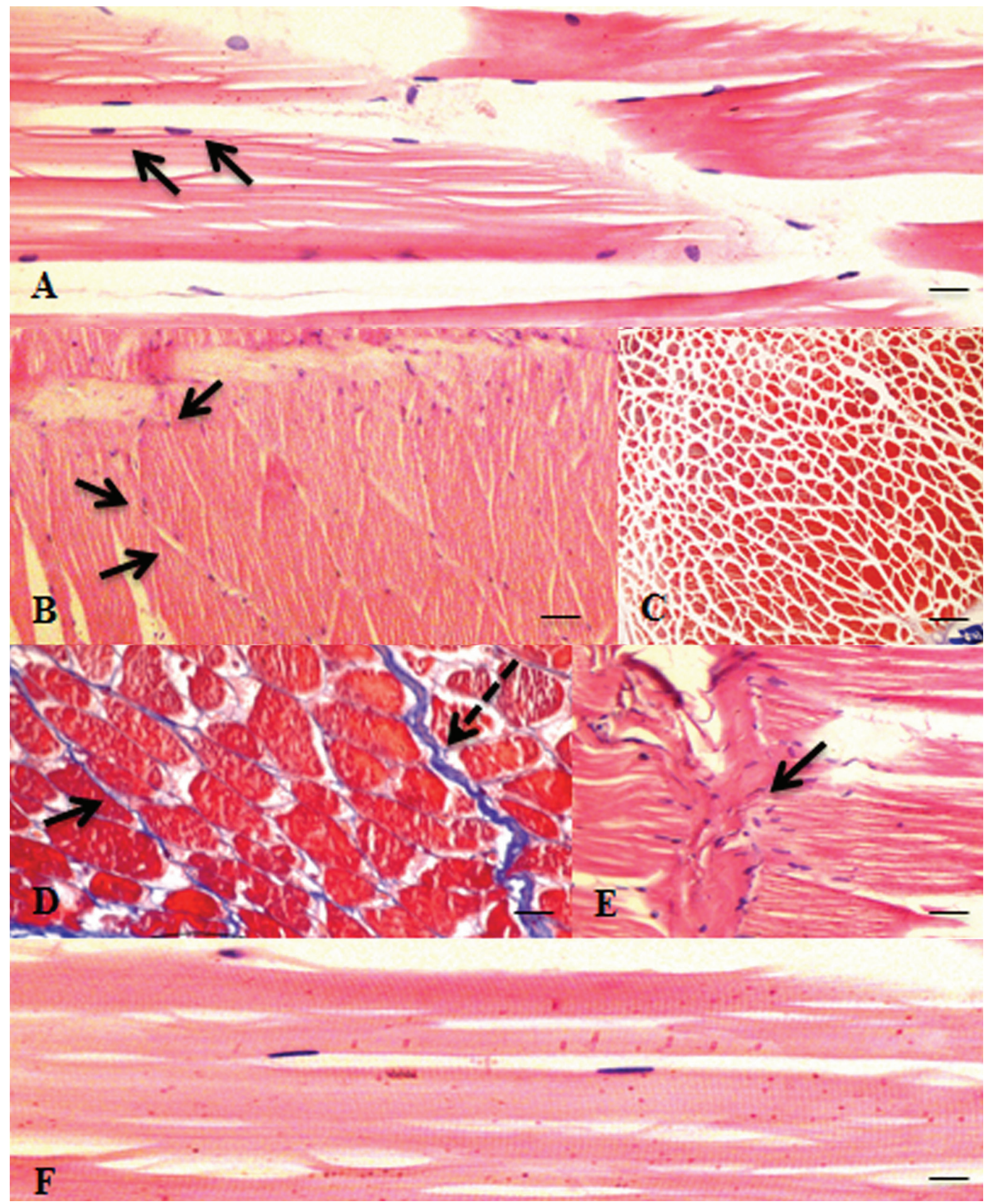

Fig. 1. Muscle tissue organization in Colossoma macropomum. A. Multinucleated fibers with peripheral nuclei (arrow). Longitudinal section. HE. $(B a r=25 \mu m)$. B. Nuclei located at the periphery of the muscle fiber (arrow). Transverse section. HE. (Bar $=50$ $\mu m)$. C. Fascicle organized in perimysium and endomysium. Transverse section. HE. $($ Bar $=100 \mu m)$. D. Connective tissue surrounding the endomysium (dotted arrow) and perimysium (black arrow). Transverse section. Masson trichrome. $($ Bar $=50 \mu m)$. E. Mobilization of cells in the muscle fiber insertion in connective tissue (black arrow), many nuclei are observed. Longitudinal section. HE. $(\operatorname{Bar}=50 \mu m)$. F. Sarcomere with striations along the muscle fiber. Longitudinal section. HE. $(\operatorname{Bar}=25 \mu m)$. 


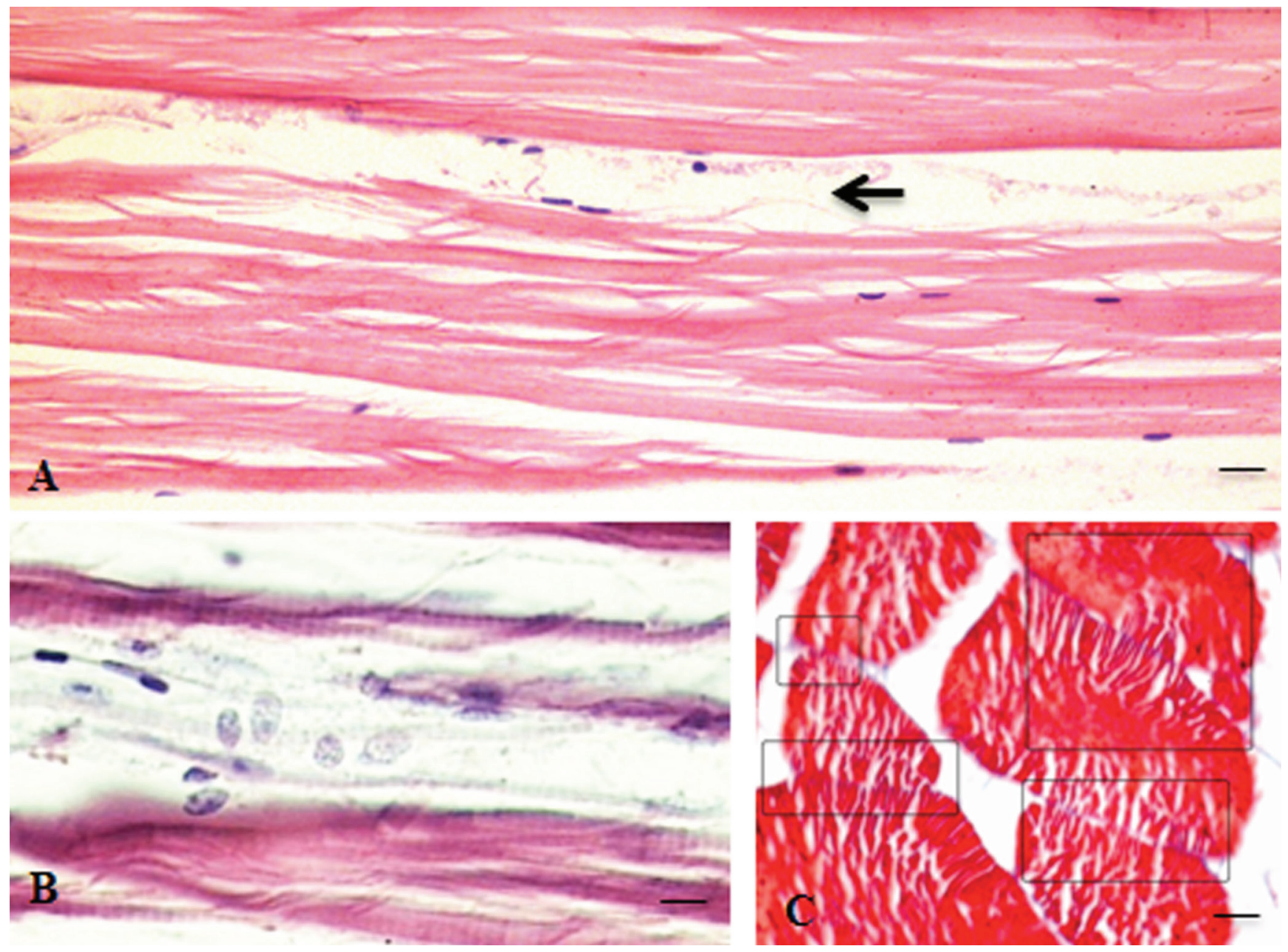

Fig. 2. A. Young muscle fibers running up. Cytoskeleton and nuclei (arrow). Longitudinal section. HE. $($ Bar $=50 \mu m)$. B. Detail cytoskeleton during fusion of the muscle fiber. Longitudinal section. HE. (Bar $=25 \mu m)$. C. Fusion side of young fibers (square). Transverse section. Masson trichrome. $(\mathrm{Bar}=25 \mu \mathrm{m})$.

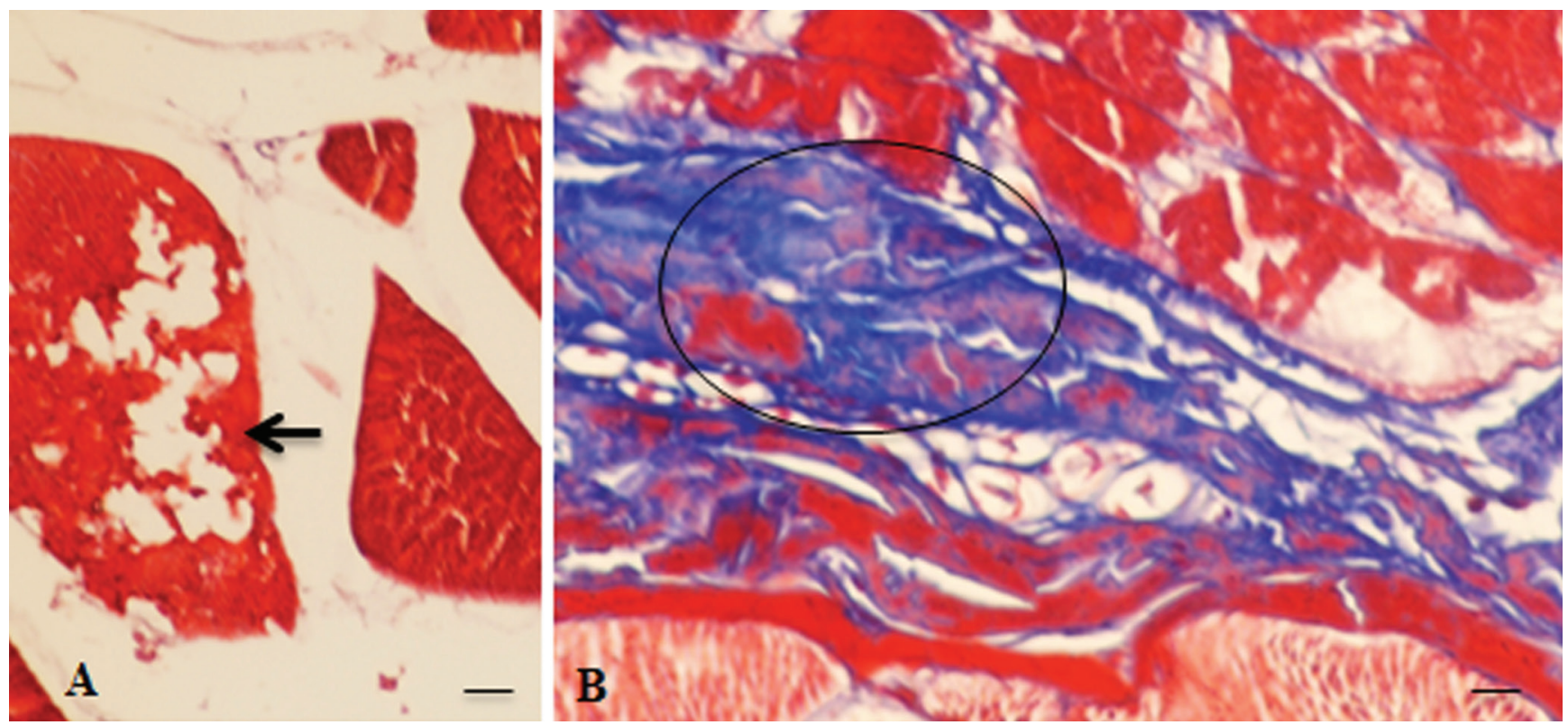

Fig. 3. A. Cellular apoptosis (black arrow). Transverse section. Masson trichrome. $($ Bar $=25 \mu m)$. B. Detail of the nerve (black circle). Transverse section. Masson trichrome. (Bar $=50 \mu m)$. 


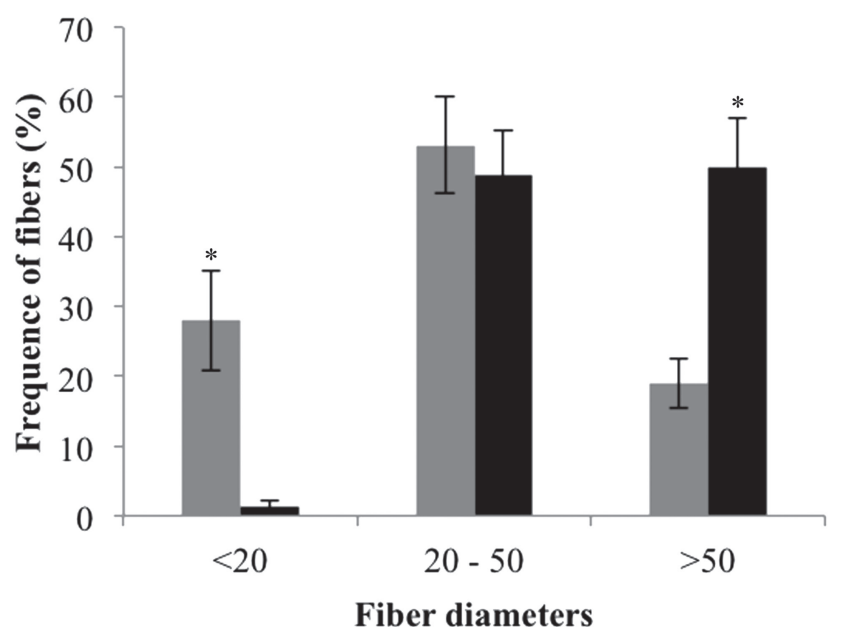

Fig. 4. Frequency of muscle fibers from 300 days old Colossoma macropomum. Significant differences $(*)$ represent the differences between the animal groups according to body weight, 165 to $300 \mathrm{~g}$ (black) and 976 to $1,250 \mathrm{~g}$ (gray) in each class by ANOVA one-way supplemented by Tukey's test $(P<0.05)$.

$$
\begin{gathered}
\mathrm{y}=0.0883 \mathrm{x}+191.77 \\
\mathrm{r}=0.45 ; p<0.0001
\end{gathered}
$$

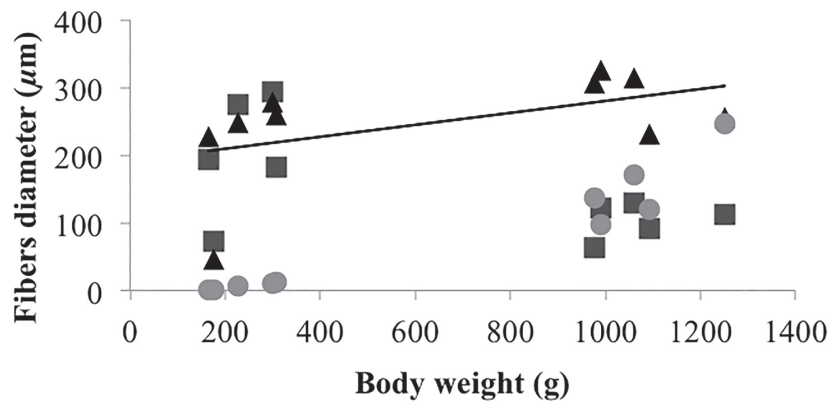

Fig. 5. Correlation between the fibers diameters and body weight from 300 days old Colossoma macropomum. The fibers diameters are showed by class: circle $(<20 \mu \mathrm{m})$, triangle (20 to $50 \mu \mathrm{m})$ and square ( $>50 \mu \mathrm{m})$.

Body growth process due to increase in number of fiber diameter observed in tambaqui, as well as other fish species, is different from mammals. For example, in adult rabbits muscle growth is due the hypertrophy process on white fibers (Dal Pai \& Curi, 1992); in contrast, muscle growth in fish at juvenile and young-adult stages is by hyperplastic process (Stickland, 1983; Rowlerson \& Veggetti, 2001). The contribution of hyperplasia to muscle growth in tambaqui described here is in accordance with results of morphometric studies carried out in the same and related species (Dal Pai et al., 2000; Silva et al., 2009; Alves-Costa et al., 2013). Appearance of "mosaic fibers" observed in the tambaqui muscle resulted from the growth by hyperplasia, increase of fiber numbers, which occurs mainly during the juvenile phase in species that reach large final size. Muscle growth by hyperplasia is very important in commercial aquaculture because it is correlated with the fillet yield. The growth by increase of fiber number is greatly reduced or entirely lacking in species such as zebrafish, guppies, and the other fish which remain small (Rowlerson $\&$ Veggetti, 2001). The occurrence of smaller diameter fibers represents a continuation of myogenesis during young-adult life. The absence of such small fibers in the caudal region of adult rainbow trout $(>39 \pm 40 \mathrm{~cm})$ was associated with the end of hyperplasia growth (Stickland, 1983; Weatherley \& Gill, 1985; Weatherley, 1990).

In this study was observed a positive correlation between muscle fiber diameter and both body weight and sex, however, in the growth curves study there were no differences in growth performance between males and females until sex maturity (400 days) (Mello et al., 2015).

Muscle growth in 300-day-old tambaqui occurs through both hyperplasic and hypertrophic growth process, giving an appearance of mosaic to muscle at transversal cut. This growth with mosaic appearance is due to the fibers of different diameters, characteristic of large size species. The muscle morphology is typical of other muscle tissues showing the same tissues and cells organizations. There are correlations between the fiber diameters with the sex, however no correlation between the body weight and sex was found in tambaqui.

\section{Acknowledgements}

The authors thank Boa Esperança Fish Farm (RondôniaBrazil) for the partnership in research and Conselho Nacional de Desenvolvimento Científico e Tecnológico $(\mathrm{CNPq})$ for the scholarship granted to the first author.

\section{References}

Alves-Costa, F. A., C. M. Barbosa, R. C. M. Aguiar, E. A. Mareco \& M. Dal Pai-Silva. 2013. Differential expression of myogenic regulatory factor genes in the skeletal muscles of tambaqui Colossoma macropomum (Cuvier 1818) from Amazonian black and clear water. International Journal of Genomics, 2013: 1-9.

Assis, C. R. D., I. P. G. Amaral, P. F. Castro, L. B. J. Carvalho \& R. S. Bezerra. 2007. Effect of dichlorvos on the acetylcholinesterase from tambaqui (Colossoma macropomum) brain. Environmental Toxicology and Chemistry, 26: 1451-1453.

Assis, C. R. D., P. F. Castro, I. P. G. Amaral, E. V. M. M. Carvalho, L. B. Carvalho \& R. S. Bezerra. 2010. Characterization of acetylcholinesterase from the brain of the Amazonian tambaqui (Colossoma macropomum) and in vitro effect of organophosphorus and carbamate pesticides. Environmental Toxicology and Chemistry, 29: 2243-2248.

Bancroft, J. D. \& M. Gamble (Eds.). 2007. Theory and practice of histological techniques. Philadelphia, Churchill Livingstone, $744 \mathrm{p}$.

Carneiro, P. C. F., H. C. Azevedo, J. P. Santos \& A. N. Maria. 2012. Cryopreservation of tambaqui (Colossoma macropomum) semen: extenders, cryoprotectants, dilution ratios and freezing methods. Cryo Letters, 33: 385-393. 
Corrêa, C. F., L. H. de Aguiar, L. M. Lundstedt \& G. Moraes. 2007. Responses of digestive enzymes of tambaqui (Colossoma macropomum) to dietary cornstarch changes and metabolic inferences. Comparative Biochemistry and Physiology - Part A: Molecular \& Integrative Physiology, 147: 857-862.

Dal Pai, V., M. Dal Pai-Silva, E. D. Carvalho, C. Y. Fujihara, E. A. Gregorio \& P. R. Curi. 2000. Morphological, histochemical and morphometric study of the myotomal muscle tissue of the pacu (Piaractus mesopotamicus Holmberg 1887: Serrasalminae, Characidae, Teleostei). Anatomia, Histologia, Embryologia: Journal of Veterinary Medicine Series C, 29: 283-289.

Dal Pai, V. \& P. R. Curi. 1992. Crescimento pós-natal do coelho Norfolk: correlação entre parâmetros somáticos e área dos tipos de fibras musculares. Pesquisa Agropecuária Brasileira, 27: 1623-1633.

Dubowitz, V. (Eds.). 1973. Muscle biopsy: a modern approach. London, W. B. Saunders, 475p.

Galo, J.M., R. P.,Ribeiro, D. P. Streit Júnior, D. M. Albuquerque, D. C. Fornari, C. F. C. Roma \& L. R. J. Guerreiro. 2015. Oocyte quality of tambaqui (Colossoma macropomum) during the reproductive season. Revista Brasileira de Biologia, 75: 279-284.

Goulding, M. \& M. L. Carvalho. 1982. Life history and management of the tambaqui (Colossoma macropomum, Characidae): an important Amazonian food fish. Revista Brasileira de Zoologia, 1: $107-133$.

Marcuschi, M., T. S. Espósito, M. F. M. Machado, I. Y. Hirata, M. F. M. Machado, M. V. Silva, L. B. Carvalho Júnior, V. Oliveira \& R. S. Bezerra. 2010. Purification, characterization and substrate specificity of a trypsin from the Amazonian fish tambaqui (Colossoma macropomum). Biochemical and Biophysical Research Communications, 396: 667-673.

Maria, A. N., H. C. Azevedo, J. P. Santos \& P. C. F. Carneiro. 2012. Hormonal induction and semen characteristics of tambaqui Colossoma macropomum. Zygote, 20: 39-43.

Mei, J., \& J. F. Gui. 2015. Genetic basis and biotechnological manipulation of sexual dimorphism and sex determination in fish. Science China Life Sciences, 58: 124-136.

Mello, F., C. A. L. Oliveira, R. P. Ribeiro, E. K. Resende, J. A. Povh, D. C. Fornari, R. V. Barreto, C. Mcmanus \& D. P. Streit Júnior. 2015. Growth curve by Gompertz nonlinear regression model in female and males in tambaqui (Colossoma macropomum). Anais da Academia Brasileira de Ciências, 87: 2309-2315.

Ministério da Pesca e Aquicultura. 2013. Boletim estatístico da pesca e aquicultura: Brasil 2011. Available from: http://www.mpa.gov. br/files/docs/Boletim_MPA_2011_pub.pdf. (20 April 2014).

Rescan, P. -Y., J. Montfort, A. Fautrel, C. Rallière \& V. Lebret. 2013. Gene expression profiling of the hyperplastic growth zones of the late trout embryo myotome using laser capture microdissection and microarray analysis. BMC Genomics, 14: 173.

Rocha, C. A. M., L. A. Cunha, R.H. Pinheiro, M. Bahia \& R. M. R. Burbano, 2011. Studies of micronuclei and other nuclear abnormalities in red blood cells of Colossoma macropomum exposed to methylmercury. Genetics and Molecular Biology, 34: 694-697.
Romanello, M. G., P. A. Scapolo, S. Luprano \& F. Mascarello. 1987. Post-larval growth in the lateral white muscle of the eel, Anguilla anguilla. Journal of Fish Biology, 30: 161-172.

Rowlerson, A. \& A. Veggetti. 2001. Cellular mechanisms of postembryonic muscle growth in aquaculture species. Pp. 103140. In: Hoar, W. S. \& Farrell, A. P. \& I. A. Johnston (Eds.) Muscle development and growth. San Diego, Academic Press. (Fish physiology, v. 18).

Schneider, C. A., W. S. Rasband \& K. W. Eliceiri. 2012. NIH Image to ImageJ: 25 years of image analysis. Nature Methods, 9: 671-675.

Silva, P., L. M. P. Valente, M. Olmedo, M. H. Galante, R. A. F. Monteiro \& E. Rocha. 2009. Hyperplastic and hypertrophic growth of lateral muscle in blackspot seabream Pagellus bogaraveo from hatching to juvenile. Journal of Fish Biology, 74: 37-53.

Sipaúba-Tavares, L. H. \& F. M. S. Braga. 2007. The feeding activity of Colossoma macropomum larvae (tambaqui) in fishponds with water hyacinth (Eichhornia crassipes) fertilizer. Brazilian Journal of Biology, 67: 459-466.

Stern, M. M., R. L. Myers, N. Hammam, K. A. Stern, D. Eberli, S. B. Kritchevsky, S. Soker \& M. Van Dyke. 2009. The influence of extracellular matrix derived from skeletal muscle tissue on the proliferation and differentiation of myogenic progenitor cells ex vivo. Biomaterials, 30: 23932399.

Stickland, N.C. 1983. Growth and development of muscle fibres in the rainbow trout (Salmo gairdneri). Journal of Anatomy, 137: 323-333.

Van Raamsdonk, W., L. van't Veer, K. Veeken, T. te Kronnie \& S. de Jager. 1982. Fiber type differentiation in fish. Molecular Physiology, 2: 31-47.

Vazzoler, A. E. A. M. 1996. Biologia da reprodução de peixes teleósteos: teoria e prática. Maringá, Eduem, 169p.

Veggetti, A., F. Mascarello, P. A. Scapolo, A. Rowlerson \& C. Carnevali. 1993. Muscle growth and myosin isoform transitions during development of a small teleost fish, Poecilia reticulata (Peters) (Atheriniformes, Poeciliidae): a histochemical, immunohistochemical, ultrastructural and morphometric study. Anatomy and Embryology, 187: 353361.

Volkoff, H., L. J. Hoskins \& S. M. Tuziak. 2010. Influence of intrinsic signals and environmental cues on the endocrine control of feeding in fish: potential application in aquaculture. General and Comparative Endocrinology, 167: 352-359.

Weatherley, A. H. 1990. Approaches to understanding fish growth. Transactions of the American Fisheries Society, 119: 662-672.

Weatherley, A. H. \& H. S. Gill, 1984. Growth dynamics of white myotomal muscle fibres in the bluntnose minnow, Pimephales notatus Rafinesque, and comparison with rainbow trout, Salmo gairdneri Richardson. Journal of Fish Biology, 25: 13-24.

Weatherley, A. H. \& H. S. Gill. 1985. Dynamics of increase in muscle fibers in fishes in relation to size and growth. Experientia, 41: 353-354. 
Weatherley, A. H., H. S. Gill \& A. F. Lobo. 1988. Recruitment and maximal diameter of axial muscle fibres in teleosts and their relationship to somatic growth and ultimate size. Journal of Fish Biology, 33: 851-859.

Yin, H., F. Price \& M. A. Rudnicki. 2013. Satellite cells and the

Submitted September 22, 2015 muscle stem cell niche. Physiological Reviews, 93: 23-67. 